\title{
Gymnomyces dominguezii sp. nov. from Spain
}

\author{
B. MORENO-ARROYO', J. GÓMEZ ${ }^{2}$ AND F. D. CALONGE \\ ${ }^{1}$ Depto. de Biología Vegetal y Ecología, Facultad de Ciencias, Universidad de Córdoba, Avda. San Alberto Magno, s/n. 14004 Córdoba, Spain \\ ${ }^{2}$ Asociación Micológica de las Sierras Subbéticas, Mesones, 4. 14800 Priego, Córdoba, Spain \\ ${ }^{3}$ Real Jardin Botánico, CSIC, Plaza de Murillo, 2. 28014 Madrid, Spain
}

Gymnomyces dominguezii, a gasteroid fungus belonging to the Russulales, is described and illustrated as a new species. Its main taxonomic characters are discussed and compared with other species in the genus and those in Martellia and Zelleromyces.

Gymnomyces was proposed by Massee \& Rodway (1898) and defined as follows: Peridium haud distinctum vel nullum. Gleba camosa, ad basin fertilis, extus intusque lacunosa, cellulis cavis ubique subaequalis; septa haud scissilia. Basidia plerunque 2-spora. Sporae globosae, hyalinae, echinulatae vel verrucosae.

Gymnomyces pallidus Massee \& Rodway and G. seminudus Massee \& Rodway were included in the genus, the first being chosen as the type. Eleven species have been added by Singer \& Smith (1960), Smith (1962), Beaton, Pegler \& Young (1984), Zhang \& Yu (1990) and Llistosella \& Vidal (1995).

On the question of the generic concept, we agree, in part, with the different opinions expressed by several authors (Pegler \& Young, 1979; Beaton et al., 1984; Thiers, 1984; Miller, 1988; Zhang \& Yu, 1990), pointing out the difficulties in separating Gymnomyces from Zelleromyces and Martellia. The chosen characters vary considerably, even within the same basidiome, which leads to artificial classifications. Amongst the proposed systematics we have chosen that given by Beaton et al. (1984).

\section{MATERIAL AND METHODS}

Microscopic observations were carried out using a Nikon Labophot, and $3 \% \mathrm{KOH}$ and Melzer's reagent. Ultramicroscopic studies were carried out as usual; samples from dried basidiomes were directly stuck onto an adhesive layer on a clean coverslip, then coated with gold and observed using a Jeol JSM-T330A SEM. The material studied is preserved in the herbaria of the senior author (BM) and the Madrid Botanic Garden (MA-Fungi).

\section{DESCRIPTION}

Gymnomyces dominguezii Moreno-Arroyo, J. Gómez \& Calonge, sp. nov.

(Figs 1-6)

Etym.: dominguezii, dedicated to Prof. E. Dominguez, from the University of Córdoba, Spain.

Basidiomata hypogea, angiocarpa, subglobosa, lobulata, $0.9-2 \mathrm{~cm}$ lata, substipitata. Peridium initio cremeum dein rufobrunneum. Gleba pallide cremea dein rufobrunnea, ex loculis minutis composita. Columella praesens. Sporae globosae vel subglobosae, 8-10 $\mu \mathrm{m}$ diam, statismosporicae, hyalinae dein pallide brunneae, amyloideae, vernucis vel reticulato partiali instructae. Basidia $25-40 \times 10-15 \mu \mathrm{m}$, clavata, 1-2-3-4-sporigera. Cystidia nulla. Basidiolae numerosae 20-50 $\times 10-15 \mu \mathrm{m}$, clavatae. Trama hymenophoralis heteromera cum hyphis filamentosis et sphaerocystis numerosis 9-15 $\mu \mathrm{m}$ diam. Subhymenium pseudoparenchymaticum.

Holotypus in Hortus Botanicus Matritensis, MA-Fungus 38572 et $B$. M. 412. Cordoba, Carretera de los Villares, subter Quercus ilex subsp. ballota, Cistus crispus et Pistacia lentiscus, aggregatus, 4-II1996, coll. B. Moreno et J. Gómez.

Basidiomata hypogeous, angiocarpous, subglobose, lobed, $0.9-2 \mathrm{~cm}$ diam., substipitate (Figs 1, 2). Peridium at first pale cream to ochraceous, drying reddish brown (Figs 1, 2). Gleba pale cream, ochraceous later, composed of cavities showing a labyrinthic structure. Columella heteromerous well-developed; sterile base present, rudimentary (Figs 1, 2). Spores globose, 8-10 $\mu \mathrm{m}$ diam., including ornamentation, statismosporic, at first hyaline then pale brown; myxosporium strongly amyloid, ornamented with a few free irregular warts and a partial reticulum (Figs 3, 4). Basidia 25-40 × 10-15 $\mu \mathrm{m}$ clavate, hyaline, changing to reddish brown in $\mathrm{KOH}$ (Fig. 5), 1-2-3-4spored; sterigmata $6-10(-14) \mu \mathrm{m}$ long. Cystidia absent. Basidioles very abundant, $20-50 \times 10-15 \mu \mathrm{m}$, clavate. Hymenophoral trama 30-40 $\mu \mathrm{m}$ thick, heteromerous with hyphae and abundant sphaerocysts 9-15 $\mu \mathrm{m}$ diam. (Fig. 6). Subhymenium pseudoparenchymatous.

Holotype: MA-Fungi 38572. B.M. 412. Córdoba, Carretera de los Villares, under Quercus ilex subsp. ballota, Cistus crispus and Pistacia lentiscus, Feb. 1996, aggregate forming colonies, leg. B. Moreno and J. Gómez. 

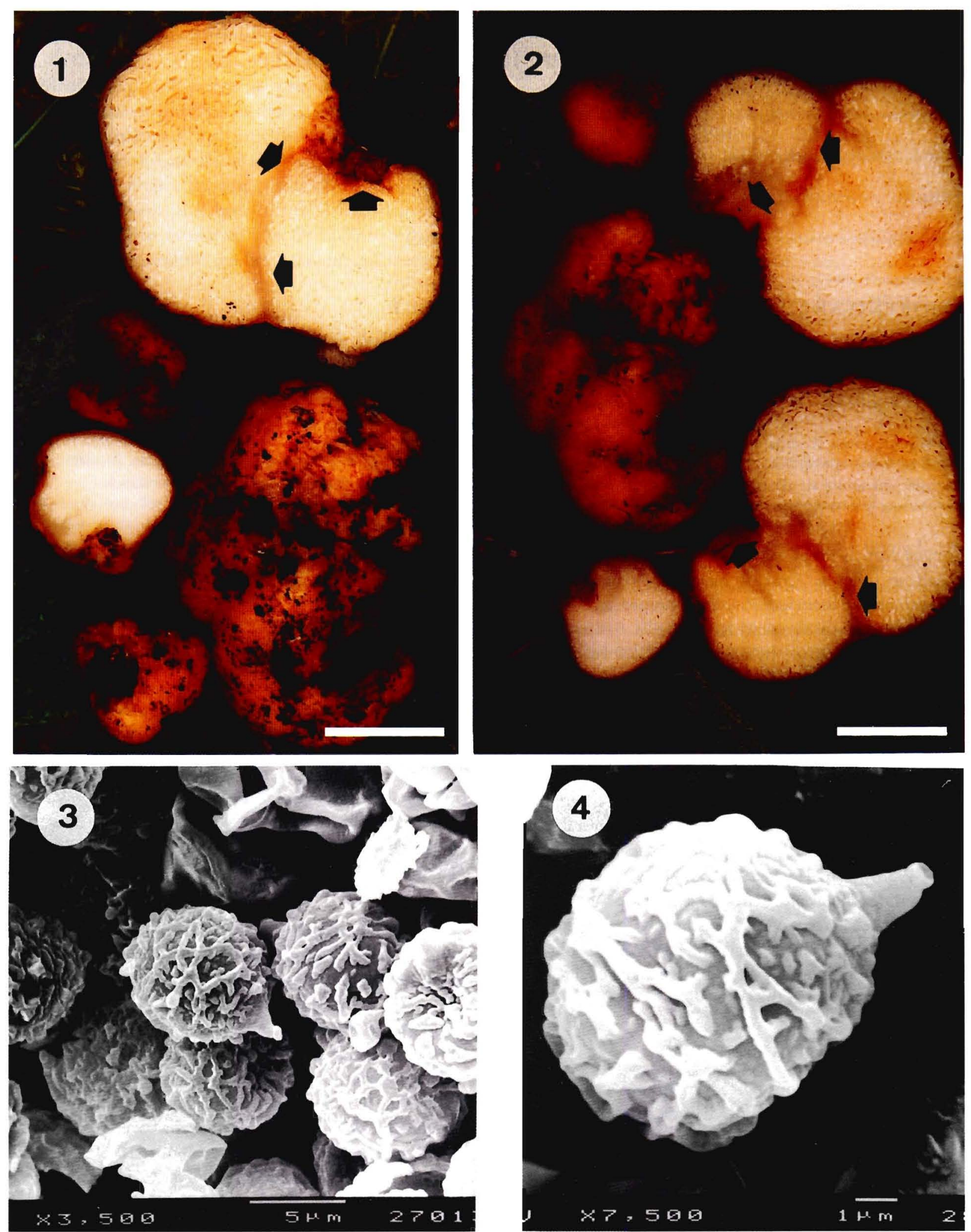

Figs 1-4. Gymnomyces dominguezii (holotype, MA-Fungi 38572). Figs 1-2. Basidiomata, complete and in section, showing cavities of the gleba, rudimentary sterile base and columella (arrows). Bar $=1 \mathrm{~cm}$. Figs 3-4. Basidiospores (SEM).

\section{DISCUSSION}

Few species of Gymnonyces already described show a clear taxonomic delimitation. Comparison of $G$. dominguezii with them, however, shows several differences when taking into consideration characters such as spore and basidium morphology as the main features (Table 1).

Table I shows that only four species have subreticulate spores, G. alveolatus Singer \& A. H. Sm., G. parksii Singer \& A. H. Sm. (Singer \& Smith, 1960), G. eildonensis G.W. Beaton, 

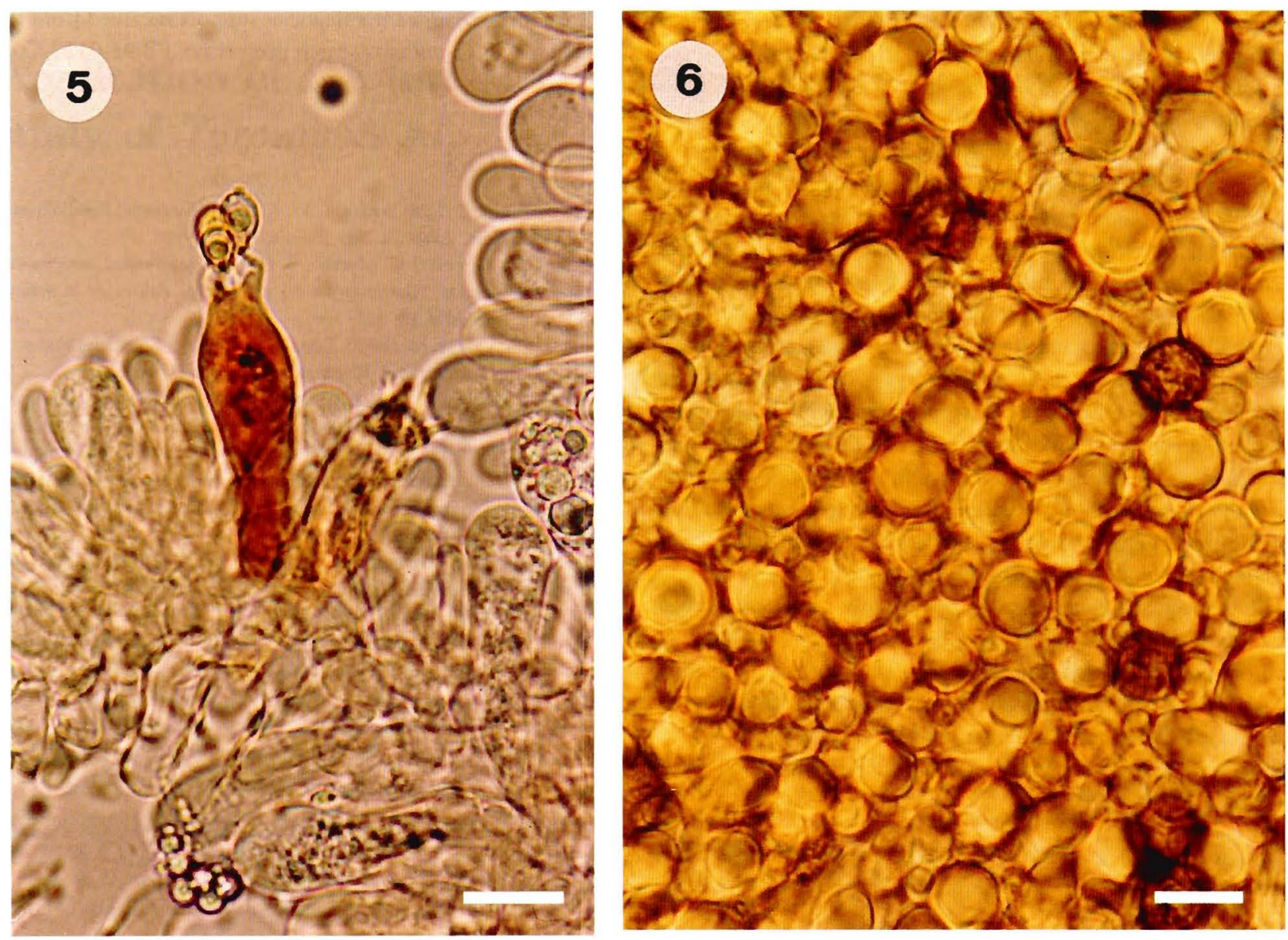

Figs 5-6. Gymnomyces dominguezii (holotype, MA-Fungi 38572). Bars $=12 \mu \mathrm{m}$. Fig. 5. Basidium after treatment in KOH. Fig. 6. Nest of sphaerocysts.

Table 1. Morphological features of spores and basıdia in Gymnomyces

\begin{tabular}{|c|c|c|c|}
\hline & Spores & Basidıa (no of spores) & References \\
\hline G. palludus & $8-9.5 \times 8-9 \mu \mathrm{m}$. spiny & $30-38 \times 12-14 \mu \mathrm{m}(2-3-4)$ & Beaton et al. (1984) \\
\hline$G$ seminudus & $9.5-13.5 \times 8.5-11.5 \mu \mathrm{m}$, spiny & $28-40 \times 8-11 \mu \mathrm{m}(1-2)$ & Beaton ef al. (1984) \\
\hline G. esldonensis & $7-9 \times 6.5-8 \mu \mathrm{m}$, subreticulate & $30-42 \times 8.5-12 \mu \mathrm{m}(4)$ & Beaton ef al. (1984) \\
\hline G. roseomaculatus & $14-17 \times 12-16 \mu \mathrm{m}$, spiny & $30-35 \times 12-14 \mu \mathrm{m}(2)$ & Singer \& Smith (1960) \\
\hline$G$ cimamomets & $9-12 \mu \mathrm{m}$ diam., spiny & $38-55 \times 10-13 \mu \mathrm{m}(4)$ & Singer \& Smith (1960) \\
\hline G. alveolatus & $9-12 \mu \mathrm{m}$ diam., subretıculate & $26-33 \times 9-11 \mu \mathrm{m}(2)$ & Singer \& Smith (1960) \\
\hline G. socialis & $9-14 \times 9-11 \mu \mathrm{m}$, spiny & $24-28 \times 11-14 \mu \mathrm{m}(2-4)$ & Singer \& Smith (1960) \\
\hline G. compactus & $10-14 \times 9-12 \mu \mathrm{m}$, spiny & $20-33 \times 9-12 \mu \mathrm{m}(4)$ & Singer \& Smith (1960) \\
\hline$G$ ferrugmascens & $11-14.5 \times 9-12 \mu \mathrm{m}$, spiny & $35-60 \times 11-14 \mu \mathrm{m}(2-4)$ & Singer \& Smith (1960) \\
\hline$G$ parksn & $8-11 \times 7-9 \mu \mathrm{m}$, subreticulate & $33-34 \times 9-11 \mu \mathrm{m}(2-4)$ & Singer \& Smith (1960) \\
\hline$G$ xanthosporus & $10-15 \times 10-14 \mu \mathrm{m}$, spiny & $30-45 \times 12-16 \mu \mathrm{m}(2)$ & Smith $(1962)$ \\
\hline$G$ latifer & $12-14 \mu \mathrm{m}$, spiny & $30-45 \times 7-10 \mu \mathrm{m}(2)$ & Zhang \& Yu (1990) \\
\hline$G$ shas & $9-11(-13) \mu \mathrm{m}$, spiny & $33-51 \times 10-15 \mu \mathrm{m}(1-2)$ & Llistosella \& Vidal (1995) \\
\hline$G$ dorminguezll & $8-10 \mu \mathrm{m}$ diam., subreticulate & $25-40 \times 10-15 \mu \mathrm{m}(1-2-3-4)$ & Present study \\
\hline
\end{tabular}

Pegler \& T.W. K. Young (Beaton et al., 1984) and G. dominguezir but in the first three their basidia do not change in $\mathrm{KOH}$ and they lack a developed columella. Only in G. alveolatus can a rudimentary columella be appreciated, in contrast to the well-developed one in G. socialis Singer \& A. H. Sm. and G. ilicis Vidal \& Llistosella (Singer \& Smith, 1960; Llistosella \& Vidal, 1995). In G. cinnamomeus Singer \& A. H. $\mathrm{Sm}$. the basidia change in $\mathrm{KOH}$ (Singer \& Smith, 1960). Gymnomyces dominguezii has a well-developed columella and the basidia are reddish brown in $\mathrm{KOH}$. The rest of the species are differentiated by having spinose spores. Thus, we consider that $G$. dominguezii combines a series of unique features, not observed in any other taxa within this genus.

A controversial and difficult question is that related to the delimitation of Gymnomyces, Martellia and Zelleromyces. Zhang \& Yu (1990), have discussed this subject and consider spore omamentation as a good character to separate Zelleromyces, whose basidiospores have a regular to irregular reticulum, from Martellia and Gymnomyces, with spinose ornamentation. From our own experience, however, this 
character is not always so easy to distinguish, since warts and partial reticulum may be associated on the spores from a single basidiome or even on the same spore, as in the case of $G$. eildonensis (Beaton et al., 1984). If we consider the other features, e.g. laticiferous hyphae and columella, the problem is similar, with characters of only relative usefulness. For Beaton et al. (1984) Gymnomyces lacks laticiferous elements and columella, but Singer \& Smith (1960) described G. socialis and G. alveolatus with a columella, in parallel to $G$. illicis (Llistosella \& Vidal, 1995). Gymnomyces dominguezii also shows a clear columella. Regarding laticiferous hyphae, Zhang \& Yu (1990) indicate that in Gymnomyces this type of hypha may be present or absent. Sphaerocysts are, in our opinion, the more stable character, and may form nests, as in Gymnomyces and Zelleromyces, or appear scattered, as in Martellia. We believe that the present chaotic situation concerning the delimitation of the three genera could be clarified by applying molecular biology techniques, such as DNA sequencing.

In respect to Gymnomyces in Spain, only G. ilicis has been recorded (Llistosella \& Vidal, 1995). Calonge, Gómez \& Moreno (1994) recorded G. ferruginascens Singer \& A. H. Sm. from Spain, but a reexamination of that material has shown it to be a new species of Zelleromyces currently being described (Moreno-Arroyo, Gómez \& Calonge, unpublished).

The authors are grateful to $\mathrm{Mr} \mathrm{M}$. Jerez for valuable SEM assistance and to $\mathrm{Mr} \mathrm{J}$. C. Hernández for word processing.
F. D. C. acknowledges the financial support received from the DGES and CSIC, under research project no. PB 95-0129-C0301.

\section{REFERENCES}

Beaton, G., Pegler, D. N. \& Young, T. W. K. (1984). Gasteroid Basidiomycota of Victoria State, Australia. Kew Bulletin 39, 669-698.

Calonge, F. D.. Gómez, J. \& Moreno, B. (1994). Gymnomyces fermuginascens Singer \& A. H.Sm. (Gasteromycetes) en España. Boletin de la Sociedad Micológica de Madrid 19, 305-306.

Llistosella, J. \& Vidal, J. M. (1995). Due nuove specie di Russulales gasteroidi della regione mediterranea. Rivista di Micologia 2, 149-162.

Massee, G. \& Rodway, L. (1898). DCIX. Fungi Exotici. Tasmania. Gymnomyces. Bulletin of Miscellaneous Information of the Royal Botanic Gardens, Kew. nos 136-137, 125 .

Miller, S. L. (1988). A systematic evaluation of basidiospore symmetry and tegumentation in hypogeous and gasteroid Russulales. Canadian Joumal of Botany 66, 2561-2573.

Moreno-Arroyo, B., Gómez, J. \& Calonge, F. D. (1998). Zelleromyces meridionalis (Russulales, Elasmomycetaceae), a new species from Spain. Mycotaxon (in preparation).

Pegler, D. N. \& Young, T. W. K. (1979). The gasteroid Russulales. Transactions of the British Mycological Society 72, 353-388.

Singer, R. \& Smith, A.H. (1960). Studies on secotiaceous fungi. IX The astrogastraceous series. Memoirs of the Torrey Botanical Club 21, 1-112.

Smith, A. H. (1962). Notes on astrogastraceous fungi. Mycologia 54, 626-639.

Thiers, H. D. (1984). The genus Arcangeliella Cav. in the Westem United States. Sydowia 37, 296-308.

Zhang, B. C. \& Yu, Y. N. (1990). Two new species of gasteroid Russulales from China, with notes on taxonomy of Gymnomyces, Martellia and Zelleromyces. Mycological Research 94, 457-462. 